\section{Paralelismos entre ilustradores de libros para niños: Vladimir Lébedev y Ayax Barnes}

Flavia M. J. Krause ${ }^{(1)}$

Resumen: Vladimir Lébedev (1891- 1967) subscribe a las corrientes vanguardistas históricas para la creación de imágenes de libros infantiles en un programa especial de publicaciones en la Revolución Rusa. Mi hipótesis es que su trabajo influyó en el de Ayax Barnes (1926-1994), ilustrador argentino que participó en proyectos innovadores de libros para niños durante los años sesenta y setenta en Argentina.

Mi análisis muestra que, a pesar de la distancia temporal y geográfica entre ellos, se pueden establecer paralelismos en cuanto a las elecciones desde lo estético, las corrientes artísticas que los influyen y la intencionalidad comunicativa de sus ilustraciones, vinculada al compromiso social y político.

Palabras clave: Libros para niños - Ilustraciones - Vanguardias - Artistas comprometidos - Elecciones estéticas.

[Resúmenes en inglés y portugués en las página 278]

(1) Profesora en Letras (UBA). Especialista en Literatura Infantil y Juvenil (UNSAM). Maestría en Diseño y Comunicación (FADU-UBA) - en curso. Investigadora en Formación en un UBACYT sobre Literatura Infantil y Juvenil. Profesora de Literatura Infantil en Profesorados de nivel Inicial y Primario de Caba. Profesora de Semiología (C.B.C.-UBA). profesorafkrause@gmail.com

\title{
Introducción
}

El estudio de la obra de un artista implica analizar las elecciones de corrientes estéticas que ha tomado, las temáticas, el contexto de producción, el momento histórico en el que ha realizado su trabajo. Si se trata, además, de artistas que ilustran libros u otros soportes, tendremos en cuenta cómo concibieron la obra en función de los destinatarios a los que se dirigían. El análisis de la obra de un artista, además, se realiza considerando las influencias de importantes representantes del arte y, específicamente, del ámbito en el que desarrolla su trabajo. 
Nos ocuparemos de dos artistas, uno ruso, Vladimir Lébedev (1891-1967) y el otro argentino, Ayax Barnes (1926-1994). No es posible establecer con certeza que Barnes sea un continuador de la obra de Lébedev cuando ambos vivieron y realizaron su trabajo en tiempos y lugares tan distantes. Sin embargo, consideramos que la obra de ambos tiene puntos de contacto, similitudes que vuelven interesante la comparación. Nos centramos en los trabajos que han realizado en los libros para niños en los que ambos se han destacado especialmente.

El artista ruso es reconocido en la actualidad como uno de los autores pioneros de la ilustración moderna de libros infantiles. En nuestro país, en cambio, recién en estos últimos años se está rescatando el trabajo de Barnes realizado previamente a su exilio en Europa debido a la última dictadura de nuestro país, para destacar su tarea y reconocerlo como iniciador de una nueva corriente de ilustración en los libros para niños.

Ambos desarrollaron su profesión en contextos históricos convulsionados desde lo político y social y de allí que han tomado partido y se han comprometido con posiciones revolucionarias. Postulamos que, posiblemente, ese sea el motivo por el que presentan similitudes en cuanto a las decisiones estéticas que han tomado, su búsqueda artística y los proyectos culturales en los que han participado.

Vladimir Lébedev ha subscripto a las vanguardias históricas, en particular al Constructivismo y al cubismo, que responden al contexto de producción de su obra. Es imprescindible analizar sus primeros trabajos como creador de carteles cuyo objetivo era informar al público de las noticias políticas y bélicas, conocidas como "las ventanas de la Rosta" y su participación en las revistas satíricas para estudiar su trabajo en los libros para niños. Entre sus libros ilustrados, elijo centrarme en dos de ellos, El helado y Ayer y hoy ${ }^{1}$ ilustrados por Lébedev en 1925 para acompañar los textos de S. Marshák, prolífico escritor de cuentos para niños, durante la época de la Revolución Rusa (1917). Estos dos cuentos nos resultan sumamente útiles para nuestro análisis.

Por su lado, en sus comienzos, Ayax Barnes se dedicó al diseño gráfico de manera autodidacta en la Imprenta AS en Uruguay, imprenta que se ha convertido en un referente de los diseñadores en ese país. Estos primeros trabajos sentaron las bases de las propuestas de Barnes en las ilustraciones para niños que realizó luego en nuestro país. Nos interesan especialmente las imágenes creadas por Barnes para la colección Polidoro del CEAL en 1967, una publicación muy valiosa como propuesta artística innovadora en su época, para los niños. Nos ocuparemos, además, de dos obras ineludibles para estudiar el trabajo de este artista, dos libros que realizó Barnes junto a su esposa Beatriz Doumerc publicados en 1975: La línea y El pueblo que no quería ser gris, en los que los autores muestran explícitamente su compromiso político en los libros infantiles.

Centramos nuestro estudio en los ilustradores de los libros para niños porque en muchos casos, las imágenes no son un añadido suntuario sino que completan información de los textos. Tal es así que, las características de las imágenes, las decisiones que han tomado los artistas para crearlas y presentarlas en los libros nos señalan una configuración de niño particular que se desprende en esos libros desde la gráfica, algunas veces tan o más enriquecedora que los textos de los escritores. Justamente, los artistas elegidos han realizado ilustraciones tan potentes que tiene sentido el recorrido más detenido de las mismas. Esta postura, de centrarse en las ilustraciones de los libros, no suele ser la más frecuente. 
Consideramos que hoy en día, el peso de la comunicación visual se esta revalorizando y el análisis del arte gráfico en los libros, sobre todo en los que se dirigen a los niños, ha cobrado necesaria relevancia.

Nos ocupamos, en primer lugar, de la manera en la que los ilustradores abrevaron en las corrientes vanguardistas e incluimos un apartado para explicar de qué manera el arte popular participa en la obra de estos ilustradores. A continuación analizamos el componente político que los atraviesa a ambos en función de la forma en la que cada uno se vincula con el contexto sociopolítico de su época y de qué modo piensan en la infancia en esos contextos. Nos detenemos, entonces, para analizar más detalladamente algunos de los cuentos que ilustraron. Estas lecturas puntuales se irán insertando en los distintos apartados. Describimos, además, los proyectos de publicación de libros para niños en los que participaron y en todo momento, estableceremos los puntos de contacto, las similitudes en la obra de ambos y aquello que los distingue.

\section{Las corrientes vanguardistas}

Lébedev no retoma del movimiento cubista que llega a Rusia la nueva visión del mundo que propone esta vanguardia en sus inicios, sino que lo incorpora como una experiencia formal, una nueva manera de crear, un método de aprendizaje. El mismo ilustrador ruso manifestaba lo que había significado el cubismo para él: "mi cubismo no es exactamente como el que formulan los teóricos del arte. En los años 20, nosotros luchábamos contra el estilo afectado y queríamos que el arte figurativo fuera eso, figurativo, pero no ilustrativo" (Cit. en: Koval, 2012, p.18). Por su lado, el especialista Eugenio Carmona postula que el cubismo planteó tres diferencias con el resto de las vanguardias. La primera es que se presenta como una fuerte alternativa al orden visual del Renacimiento: la multiplicidad de perspectivas frente a una única. El cubismo además separaba realmente las nociones de creatividad y subjetividad. Pero la tercera diferencia y la más relevante para este autor, es que "el cubismo no sólo fue germen de otras tendencias, sino que ante todo, en su propio seno, fue catalizador de experiencias y propuestas que, aun siendo en origen cubistas, tuvieron la capacidad de deslizarse o extenderse hacia otros rasgos de poética" (Carmona, 2008, p. 16).

En el caso de Lébedev, justamente, si bien él absorbe la propuesta cubista con su abstracción y sus formas geométricas, esto se transforma en experiencias formales para construir imágenes nuevas pero figurativas. De manera muy similar, Barnes retoma el cubismo pero podemos reconocer también en sus ilustraciones la presencia de otros movimientos artísticos posteriores al nacimiento de las vanguardias de los años veinte como las corrientes posteriores a la segunda guerra mundial desarrolladas en América y las propuestas de estudios de diseño de su época.

La incidencia fuerte del cubismo en ambos artistas es la primera coincidencia que encontramos. La siguiente, que se relaciona con el trabajo de ambos ilustradores como diseñadores, se refiere a la tarea como comunicadores creando carteles, afiches y publicaciones de divulgación masiva. 
La crítica Nicoletta Misler (2012) señala que Lébedev tuvo que trabajar como ilustrador desde muy joven para ganarse la vida y asegura que por este motivo tuvo conciencia muy pronto de la importancia en la comunicación entre el creador y el receptor, y cuál era su tarea como comunicador creando imágenes. De la misma manera, Barnes en sus comienzos creando afiches en la Imprenta AS, se especializó en resolver propuestas claras y potentes para interpelar al público masivo.

\section{Las vanguardias en los cuentos para niños}

Analizaremos detenidamente cuentos de los artistas que nos permitirán ejemplificar lo que postulábamos acerca de la influencia de las vanguardias cubistas en las ilustraciones para niños con la originalidad propia de cada uno.

\section{El helado (ilustrado por Lebedev)}

El cuento trata de la historia de un señor adinerado que quiere comprar muchos helados porque es su cumpleaños. Este personaje, que representa a los gordos burgueses de la época, come tanta cantidad de helados que el heladero necesita pedirle a otros colegas que le ayuden para proveerle más. A medida que el señor come, se va congelando para terminar, en forma absurda, transformado en un muñeco de nieve.

La tapa del libro El helado fue diseñada por Lébedev a partir de la construcción de imágenes con figuras geométricas (círculos, cuadrados, y otras) que sintetizan de forma abstracta el carro del heladero. Se cuida la simetría y las proporciones de manera casi matemática aunque no deja de ser figurativo y de fácil legibilidad. Por añadidura, el título del cuento funciona anclando el sentido de la imagen en el mismo carro de helados. La palabra "Helado" es el título del cuento y el epígrafe de la ilustración al mismo tiempo.

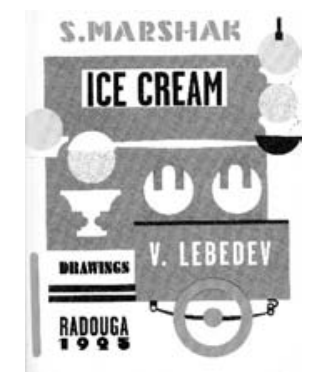

Figura 1. Tapa del libro El helado de Marshák y Lébedev extraído de Márshak, S. y Lébedev, V., The circus and other stories. London: Tate, 2013. 
Otra página que nos proponemos describir es aquella en la que se acercan varios heladeros para proveer más helados. Estos con sus carros están organizados en toda la hoja derecha, sin una base. Las figuras resaltan sobre un fondo blanco y la disposición en la hoja permite generar una visión dinámica, percibir movimiento en el espacio a través de diagonales que forman las ilustraciones. Las piezas gráficas, en este caso heladeros, están delimitadas por un círculo que los contiene. La composición de la imagen destaca los conceptos de diseño y no busca imitar a un grupo de heladeros circulando.

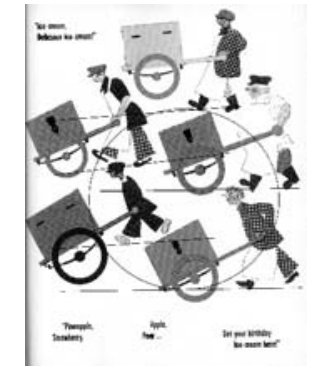

Figura 2. El helado de Marshák y Lébedev extraído de Márshak, S. y Lébedev, V., The circus and other stories. London: Tate, 2013 (las líneas añadidas no son del original).

Por otro lado, la construcción de los típicos personajes de las calles (en este caso el heladero) nos recuerda directamente las ilustraciones de los tipos de la Acera de la Revolución que fue creando el mismo Lébedev a partir de los apuntes que fue realizando en sus recorridos por las calles de Petrogrado. En esta Acera aparece, entre otros, el nepman, el nuevo burgués surgido a partir de la nueva política de restablecimiento del capitalismo y desprestigiado por la sociedad. El nepman en el cuento infantil El helado es el burgués gordo que es ridiculizado por comer excesiva cantidad de helado. Este personaje real y típico de la NEP (Nueva Política Económica) ${ }^{2}$, incluido en este cuento infantil de manera satírica, se contrapone con otros personajes irreales o fantasiosos que abundan en los libros para niños. Tanto el texto de Marshák como las imágenes de Lébedev que refuerzan las palabras en El helado, presentan una visión del mundo muy realista y con contenido político explícito. Pérez y Lévéque (2012) nos confirman que Lébedev en los cuentos para niños y otros autores de la época descartaban las hadas, las brujas y los seres fantásticos y en su lugar presentan personajes del cine o personas comunes que se dedicaban a tareas cotidianas y sociales como el cartero, el conductor de tranvías, el heladero.

Una de las originalidades de Lébedev es la incorporación de los detalles pequeños en la construcción de los personajes. Si bien tienden a la síntesis y la marcada geometría, la caracterización de estos tipos no ahorra en detalles y rasgos mínimos como el burgués con una cadena con el reloj, los botones de los zapatos, los tiradores con su botón, el diseño de la camisa y el chaleco con diferentes tipos de rayas. Es muy probable que esto se deba a la intención de asegurarse que el personaje sea reconocido como estereotipo y a la originalidad propia de este artista. 


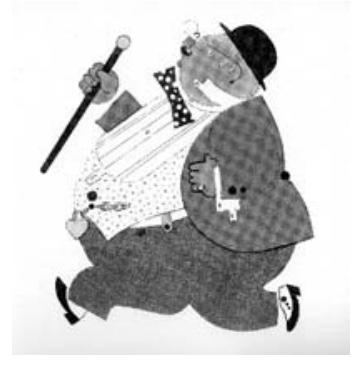

Figura 3. El helado de Marshák y Lébedev extraído de Márshak, S. y Lébedev, V., The circus and other stories. London: Tate, 2013.

\section{Ayer y hoy (ilustrado por Lebedev)}

Este segundo cuento, realizado por los mismos autores y publicado el mismo año que $E l$ helado, expone de manera muy didáctica y clara el contraste entre lo antiguo y lo moderno. Distintos objetos del ayer se presentan con sus limitaciones e inconvenientes de uso, mientras que los del hoy, salen victoriosos. La comparación en términos binarios responde a un mensaje explícito, claro y hasta redundante. En las imágenes, los objetos antiguos no son coloridos ni bien definidos, mientras que los modernos se muestran coloridos, limpios y perfectos. Desde el diseño este contraste se resuelve con la composición que permite la comparación directa. En la tapa del cuento, por ejemplo, el texto "Ayer" en la parte superior de la página está por encima de tres personajes ancianos, encorvados, sin color que portan los objetos antiguos. En la parte inferior de la página, en contraposición, otros tres personajes debajo del texto "Hoy" van erguidos: son jóvenes y coloridos.

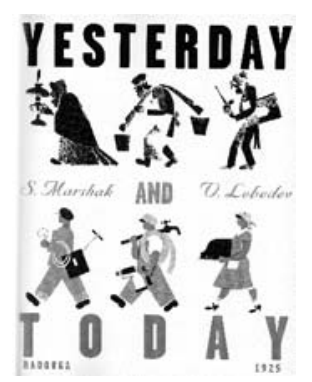

Figuras 4. Ayer y hoy de Marshák y Lébedev extraído de Márshak, S. y Lébedev, V., The circus and other stories. London: Tate, 2013.

La idea de niño que subyace en este libro es la del alumno al que se le enseña de forma directa un mensaje único. La tipografía, por añadidura, forma parte de las imágenes, del mismo modo que sucede con los libros-álbum más modernos. Literalmente la página que quiere contraponer las formas de escritura de la antigüedad versus la forma moderna, muestra en la hoja izquierda el tintero antiguo junto a algunos dibujos de personas en distintas situaciones hechas con tinta en un azul muy tenue. Se encuentran diseminadas, 
además, varias manchas de tinta haciendo evidente el inconveniente habitual de esta modalidad de escritura cuando la tinta salpicada mancha la hoja casi de manera inevitable. Del lado derecho, en cambio, la presencia de la máquina de escribir se impone limpia, con la marca comercial en un dibujo plano que ocupa media hoja y en una visión en picada. Las letras del texto, muy diferentes de las góticas y curvadas de la página izquierda, son las mecánicas de la máquina de escribir. El mensaje didáctico del cuento se asemeja a los postulados futuristas del movimiento vanguardista que exaltan de manera categórica lo mecánico, lo industrial y la máquina frente a lo artesanal.

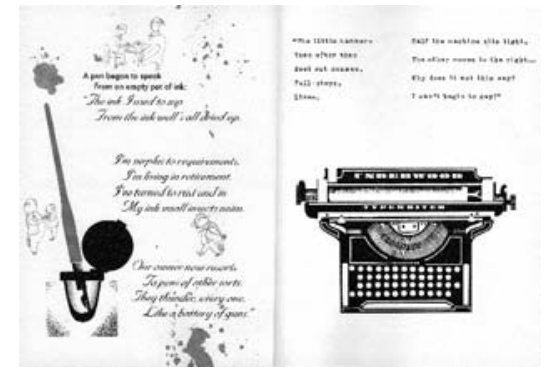

Figuras 5. Ayer y hoy de Marshák y Lébedev extraído de Márshak, S. y Lébedev, V., The circus and other stories. London: Tate, 2013.

Nos ocuparemos ahora de un cuento tradicional de Andersen ilustrado por el ilustrador argentino Ayax Barnes:

\section{El intrépido soldadito de plomo (ilustrado por Ayax Barnes)}

Para este cuento publicado en la colección Polidoro del Centro Editor de América Latina (CEAL), Barnes también construye a los personajes y distintos elementos con figuras geométricas, sintéticas y coloridas al modo cubista. Incorpora diferentes materiales en forma de collage, un procedimiento habitual de las vanguardias que eluden copiar lo real y en cambio la incluyen en forma fragmentaria pero directamente en la obra para crear una realidad nueva a través de una representación.

Barnes realiza a la bailarina del cuento, la enamorada del soldadito, a partir del recorte de un encaje rústico, para vestirla sin brillos ni miriñaques. Su figura se presenta en el marco de un castillo de papel plano con solapas a los costados y en una de ellas leemos "cortar por la línea". Es uno de aquellos juguetes de papel para recortar y armar como bricolage, un juguete económico y popular de fabricación casera, muy accesible para cualquier niño y que además, pone en primer lugar el carácter lúdico de un juguete a transformar.

En otra página, cuando el soldadito viaja en un barquito, el papel de diario hecho barco es de un matutino que circula en el tiempo de la publicación del cuento y se pega a la página sobre un fragmento de la foto del agua real. 

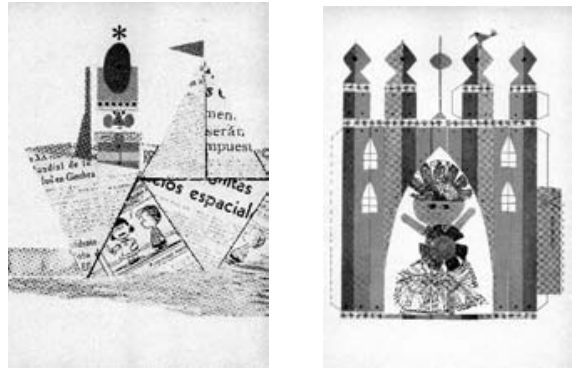

Figuras 6 y 7. El intrépido soldadito de plomo. Ilustrado por Ayax Barnes para la colección Polidoro. Buenos Aires: CEAL, 1967.

En otra doble página del cuento, con una imagen en forma exclusiva, el soldadito de plomo, realizado a partir del montaje de formas geométricas destacando el detalle de la única pierna, cae de la ventana. La ilustración muestra parcialmente un edificio de donde cae el soldadito con un fondo blanco y sin marco. El edificio ocupa más de la mitad de una de las páginas, está armado con recortes de fotos y una anciana que mira. La figura del soldadito inclinada e invertida va cayendo en un abismo sin cielo, ni piso, ni marco. El equilibrio espacial de la página se logra con la aparición del lado derecho de otro edificio que se ve parcialmente. Nuevamente podemos recordar el juego de los niños que mueven los muñecos cuando cobran vida en sus manos como el castillo de la bailarina.

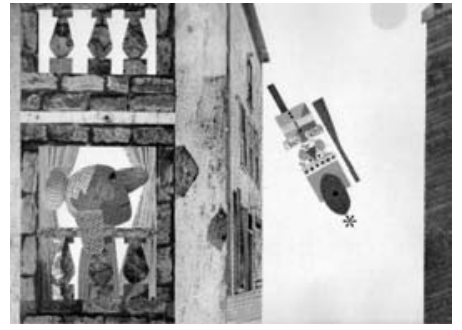

Figuras 8. El intrépido soldadito de plomo. Ilustrado por Ayax Barnes para la colección Polidoro. Buenos Aires: CEAL, 1967.

Otra doble página del cuento presenta un pez gigante comiéndose al soldadito creado a partir de recortes coloridos. Son franjas de telas que van armando un pez completamente artificial pero reconocible, figurativo a partir de elementos reales.

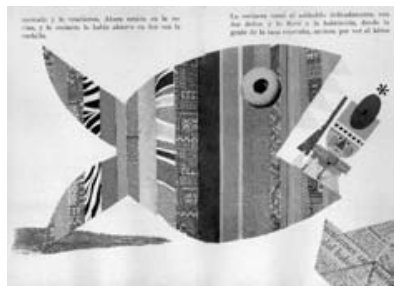

Figuras 9. El intrépido soldadito de plomo. Ilustrado por Ayax Barnes para la colección Polidoro. Buenos Aires: CEAL, 1967. 
La propuesta gráfica se corresponde con las técnicas vanguardistas del collage y el cubismo pero al mismo tiempo, reconocemos a un receptor pensado como activo y participativo con imágenes que lo invitan a crear. Las características de las vanguardias estéticas tienen muchos puntos en común con la infancia y la libertad de crear sin aferrarse a la representación fiel de lo real.

\section{Vanguardias y arte popular}

La recuperación de materiales de desecho, la búsqueda de imágenes primitivas o que eran consideradas por la academia sin valor artístico, es vital para las vanguardias que quieren producir una ruptura con el arte tradicional.

Por añadidura, estos procedimientos que forman parte del arte popular se vinculan fuertemente con la infancia, los dibujos infantiles y el arte primitivo.

Los especialistas consideran que al momento de estudiar los trabajos de los vanguardistas rusos de los años veinte, la referencia a los Lubkí, rusos, aquellas ilustraciones de producción casi artesanal, rústica y muy efectivas como comunicación que se transformaron casi en cómics populares, es ineludible. Señalan que:

Esos viejos rótulos atraían a nuestros artistas por su ingenuidad y espontaneidad, por el carácter convencional y estereotipado de la representación de los objetos, con sus libres, limpias y llamativas tonalidades. (...) Los rótulos debían resultar elegantes y expresivos; además, su diseño se orientaba a una comprensión y legibilidad instantáneas, tanto a corta como a larga distancia. Para que el rótulo no violara la integridad visual de los muros, la imagen representada debía someterse a la planitud ${ }^{3}$ (Catálogo, 2012, p.15).

Las características de las imágenes de Lébedev en los libros para niños también se corresponden con estas ilustraciones populares de "comprensión y legibilidad instantáneas".

Las ilustraciones de Barnes, en cierta medida, se parecen en parte aunque con el añadido de otros movimientos y corrientes artísticas que lo han influido. Destacamos, además, que se trata de una publicación económica la de los cuentos Polidoro, se venden en quioscos de todo el país y constituyen productos populares de distribución masiva. Esto parece contrastar con el valioso trabajo artístico por parte de Barnes y todos los artistas que participaron de la creación de imágenes, que se adivina por detrás del papel rústico y la imprecisión del color original de las ilustraciones.

En particular, las ilustraciones de Barnes incluían además la técnica del collage a partir de la recuperación de materiales reales pero, descartados, sin valor, como los retazos de telas, el papel de diario, los recortes, etc. para crear algo nuevo con lo desechado. De esta manera, se incorporaba la vida al arte, como una forma de volver a vincular el arte con la vida, con la praxis vital. 


\section{Arte y política}

El movimiento vanguardista con vínculos políticos más claros fue el Constructivismo ruso, y no es casual referirnos a él cuando estudiamos la obra de Lébedev. Los críticos Pérez y Léveque explican que:

En la URSS, la influencia del Constructivismo ha sido muy grande, a pesar de que los constructivistas son aún una minoría. Esa tendencia, uno de cuyos principios es que la pintura en un país socialista debe aplicarse exclusivamente a la decoración de las celebraciones y monumentos públicos; que rechaza la pintura de caballete y no quiere más que la puesta en escena en los teatros, la fabricación de materiales, los carteles, los frescos, los libros infantiles, etc. Ha sido efectiva porque expresa las necesidades más esenciales de la vida colectiva (Pérez y Léveque, 2012, p. 87).

El crítico Lodder, en El Constructivismo ruso, añade algunos aspectos más. Considera a este movimiento como una teoría del diseño y enfatiza la relación del arte con la producción. El contexto de este movimiento es la Revolución, el socialismo, y la obra de arte constituye un objeto construido a partir de elementos materiales organizados por un artista según determinadas técnicas análogamente al proceso de producción de un objeto:

Cuando el tema o el relieve dejaron de hacer referencia, aunque fuera muy indirecta, al objeto exterior, es decir dejaron de ser figurativos, o de contener elementos figurativos, el tema o el contenido del relieve pasaron a ser los materiales de los que estaban hechos, sus interrelaciones e interacción con su entorno espacial inmediato (Lodder, 1988, p. 75).

El Constructivismo, siguiendo el enfoque marxista, considera al arte condicionado (no aislado) y representa un arma para ser utilizada en la lucha por el socialismo. El artista como constructor conjuga lo artístico con lo técnico para producir un objeto que cumpla una función determinada. La función del objeto artístico destierra la idea de contemplación pasiva y coloca en primer plano la comunicación y la interpelación del público al modo del objeto industrial.

En el caso del libro El helado, de manera casi explícita, reconocemos estas características: es un objeto artístico, literario, y al mismo tiempo, es funcional al objetivo de educar a los niños para la revolución. En Ayer y hoy también encontramos su funcionalidad didáctica. Sin embargo, Lébedev se esmera en lo figurativo de sus ilustraciones infantiles y la experimentación con nuevos materiales no es prioritario.

Uno de los aspectos destacados de las vanguardias, señala Bürger (2000), se refiere al rechazo de estos movimientos por la autonomía del arte y al encierro por parte de los artistas que no se involucran con las esferas políticas, sociales y económicas. El arte debe vincularse con la praxis vital, con la vida y de allí que el artista tiene que vincularse de otra forma con la sociedad y la política, abandonar la "torre de marfil" y comprometerse como un trabajador del arte. Lébedev es un claro exponente de esta nueva figura de la mo- 
dernidad. El ilustrador proviene de una familia de obreros, es recordado por uno de sus discípulos, Valentín Kúrdov, de esta manera: “(...) respetaba la maestría profesional en la labor del artista y comparaba nuestro trabajo con el trabajo de un obrero, desmitificando ese concepto de -sumo sacerdocio artístico-"” (Kúrdov, 2012, p. 11).

El especialista en historia del arte De Micheli, por su parte, se refiere principalmente al contexto francés de las vanguardias, sin embargo, es posible extrapolar sus ideas al resto de Europa cuando plantea que la modernidad no implica únicamente una ruptura estética.

En esta época toma consistencia la moderna concepción de pueblo y los conceptos de libertad y de progreso adquieren nueva fuerza y concreción. (...) Las ideas liberales, anarquistas y socialistas impulsaban a los intelectuales a batirse, no sólo con sus obras, sino con sus armas en la mano (De Micheli, 1999, p. 16).

Este especialista se refiere al debate entre forma y contenido librado en la época de irrupción de las vanguardias y señala que en el período revolucionario, la realidad pasa a ser el tema central a tratar en el arte, y los artistas comprometidos con ella entienden que ya no es posible mantener una posición contemplativa y no actuar. De allí que buscan la manera, desde su lugar, de participar en lo que está sucediendo, de intervenir:

La realidad histórica se hace así contenido de la obra a través de la fuerza creadora del artista, el cual, en vez de traicionar sus características, ponía en evidencia sus valores. En otras palabras, la realidad-contenido, al actuar con su prepotente empuje dentro del artista, determinaba también la fisonomía de la obra y su forma. Este es otro punto firme de la estética madurada particularmente en aquellos años del siglo XIX. Citemos una vez más a Hegel: 'Lo que decide, tanto en el arte como en todas las obras humanas, es el contenido' (De Micheli, 1999, pp. 18-19).

Los artistas que nos ocupan, aunque distanciados en tiempo y espacio, están inmersos en estos aspectos de la modernidad.

Nos interesa volver al trabajo del artista ruso previo a la participación en la publicación de libros para niños, para explicar de algún modo, su posición frente al contexto en el que vivió. En sus comienzos, Lébedev crea dibujos satíricos en revistas destacadas como Satirikón y Nóvyi satirikón (1916-1918) con una posición anti-bolchevique pero muy pronto cambia con una clara adhesión a la Revolución. En 1918 lo nombran profesor-director de los Talleres de Arte Estatales Libres de Petrogrado dentro de la antigua Academia de Bellas Artes en el marco de las reformas revolucionarias. En este período se vincula con los principales representantes de las corrientes artísticas rusas (Tatlín, K. Malévich, M. Matiúshin y el crítico Nikolái Púnin) y además participa en GIZ (Ediciones del Estado).

Para este análisis, es preciso referirnos a "los carteles de la Rosta" realizados por Lébedev. Influido por el cubismo (que atraviesa toda su obra) es reconocido por el desarrollo de estos carteles que se colgaban en la ciudad para informar a una población, mayoritariamente analfabeta, de las noticias bélicas y políticas. En ellos identificamos algunos rasgos del cubismo en la distribución formal abstracta y austera con figuras casi geométricas que 
Lébedev crea con una muy buena síntesis y pocos colores que se distribuyen sobre el fondo blanco, creados para ser rápidamente identificables, realizados de manera estereotipada como en el caso del cartel A la salvaguardia de Octubre o El ejército Rojo y la Marina defienden las fronteras rusas (nov.-dic. 1920)

Estos carteles, además, constituyeron un antecedente fundamental en su país, como señala Koval: "El nuevo cartel ideado por Lébedev, caracterizado por su claridad conceptual e intencional y su gran capacidad política, ejerció una enorme influencia en el desarrollo del arte gráfico soviético" (Koval, 2012, p. 19) Al potencial comunicativo de los carteles, hay que añadir el carácter satírico de estos carteles que le suma más efectividad a la propuesta. Otro ejemplo es el cartel del obrero que barre burgueses con su escoba ${ }^{6}$, que reúne estas características. Estos trabajos previos del ilustrador son fundamentales al momento de estudiar y explicar las imágenes de los libros para niños que realiza posteriormente.

Cuando vamos al contexto de nuestro país en los sesenta y setenta, para referirnos al ilustrador de nuestro país, el escenario político es revolucionario también, aunque con claras diferencias con la Revolución a la que asiste Lébedev. Podemos distinguir al artista ruso que participa en la producción de libros para niños desde un organismo estatal, mientras que el artista argentino lo hace desde una editorial muy particular pero de administración privada. Algunos aspectos coyunturales los acercan y otros, los distancian.

El contexto argentino es uno de los temas tratados por la especialista en literatura latinoamericana Claudia Gilman en su libro La pluma y el fusil (2012). Allí señala que de manera gradual pero inevitable, los intelectuales y artistas de los sesenta y setenta en Latinoamérica, se fueron configurando como intelectuales comprometidos en el arte y la política, de diferentes maneras ya que cada uno debía elegir el modo que lo haría.

En cuanto al compromiso del autor, sus intervenciones en la esfera pública, su conducta, sus ideas políticas, sus estrategias frente a los enemigos de la revolución, fue una caución necesaria de la noción general del compromiso, porque éste implicaba siempre alguna clase de intervención intelectual que excedía la producción literaria o artística en cuestión (Gilman, 2012, p. 145).

La ebullición política de esta época repercute en los artistas de nuestro continente con similitudes con la etapa revolucionaria rusa y sus artistas, de una o de otra forma, se fueron comprometiendo con esa realidad política que los circundaba.

Consideramos que recién en 1975 Ayax Barnes, explícitamente, toma partido por las ideas revolucionarias en los libros para niños con La línea y El pueblo que no quería ser gris. Además de elegir las corrientes vanguardistas en el arte para acompañar las ideas políticas también de vanguardia, Barnes con estos dos libros denuncia abiertamente su disconformidad con las políticas de estado.

En 1975 la asociación cubana Casa de las Américas instala entre sus galardones un premio para libros de literatura infantil. En ese año le otorga el premio a La línea escrito por Beatriz Doumerc e ilustrado por Ayax Barnes. La institución cubana, además, lanza una tirada de 100.000 ejemplares que se agotan rápidamente y que actualmente es casi inhallable y también lo publica la editorial Granica en nuestro país. Muy pronto, al año siguiente, el libro es prohibido por decreto por la dictadura argentina. 


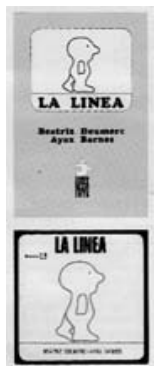

Figura 10. Tapas de las dos primeras ediciones de La línea. Extraídas de la separata que acompaña a la edición conmemorativa de los 40 años del Premio Casa de las Américas del libro La línea. (2015) Caba: Ediciones del Eclipse.

A propósito de una reedición del libro por parte de una editorial argentina en homenaje a los 40 años de su primera edición, explicaba en una separata al libro esta historia:

La línea no cuenta una historia de ficción; más bien se aproxima a una poesía combativa que arenga a la lucha. Sus autores tienen la certeza de haber escrito una obra oportuna y valiosa cuando resulta premiada. Y aún su censura posterior ayuda a confirmar el perturbador valor de denuncia que incorporaba. En el dictamen del Jurado de Casa de las Américas ${ }^{7}$ al momento de premiarla se destaca, en primer lugar, su poder de síntesis y el hecho de que se la pueda considerar para todas las edades. En segundo lugar, su sentido del humor y la adecuada inserción en el contexto socio-político de su tiempo. (...) En las antípodas del dictamen de Casa de las Américas, el texto del decreto reutiliza la fórmula de prohibición de otras obras literarias sentenciando que 'se trata de cuentos dedicados al público infantil con finalidad de adoctrinamiento que resulta preparatoria a la tarea de captación ideológica propia del accionar subversivo' (cit. en: Krause, 2015).

La fuerza gráfica y comunicativa de La línea está muy vinculada con las características de los afiches de la Imprenta AS. Nos interesa describir algo más de los comienzos del trabajo de Barnes como diseñador en esta imprenta, que indudablemente, constituyen el germen de su trabajo posterior en su obra para niños. Barnes y sus compañeros diseñadores elaboraban carteles en forma de afiches, tapas de discos y folletería en general con escasos recursos y mucha habilidad para resolver la impresión de manera innovadora con maquinarias antiguas. Realizan afiches para un teatro de títeres, "El galpón de títeres", y una discográfica, la conocida "Ayuí Tacuabé" que se caracteriza por editar discos no comerciales. Con respecto al trabajo de diseño de Barnes, rescatamos el comentario que hace el director de la discográfica, Coriún Aharonián, sobre un trabajo que le encarga a Barnes en 1972, que explica el modo de trabajar del artista:

(...) le pedí (a Ayax Barnes) un afiche a una tinta para el Primer Curso Latinoamericano de Música Contemporánea. Fue otra maravilla. Funcionaba como afiche, desplegado, y soportaba el ser doblado para ser enviado por correo sin 
mayores sobresaltos. Una vez más, resultaba llamativa su capacidad para inventar soluciones de bajo costo para iniciativas militantes (en: folleto de la muestra “Tal para cual” en el Museo de la Lengua - Biblioteca Nacional-junio 2015).

\section{El pueblo que no quería ser gris (ilustrado por Ayax Barnes)}

El otro cuento al que nos referimos antes, El pueblo que no quería ser gris, escrito por Beatriz Doumerc e ilustrado por Ayax Barnes, fue publicado por primera vez en 1975 en la editorial Rompan filas de nuestro país. En el año 1976, en el mismo decreto de la dictadura en que se prohíbe este libro, se incluye el otro libro emblemático de este matrimonio: $L a$ línea. En ambos libros, la posición revolucionaria de los autores es explícita.

El pueblo que no quería ser gris cuenta la historia de un rey muy autoritario que exige que todos pinten sus casas de gris. Uno de los pobladores decide pintarla de "rojo, azul y blanca" luego de mirar embelesado un pájaro con esos colores. De manera humorística, la historia transcurre dejando en ridículo al rey que no logra que todo permanezca gris según sus órdenes cuando los colores se expanden y llegan a manchar más allá de las fronteras de su reino.

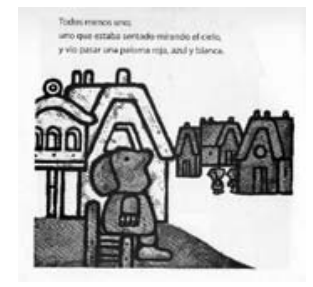

Figura 11. Doumerc, B. Y Barnes, A. El pueblo que no quería ser gris. Caba: Colihue, 2015.

Las ilustraciones que realiza Barnes para este cuento son sumamente particulares. El rey y sus guardias tienen un tamaño mayor que los pobladores, tienen formas algo toscas y cuadradas que los asemejan a seres casi mecánicos. Lo que sí comparten todos los personajes es que están representados sin rasgos particulares más que las marcas que indican su rol, al modo de los arquetipos de los cuentos tradicionales. En este libro-álbum, el texto va acompañando a las imágenes y se complementan: "Había una vez un rey grande, en un país chiquito" dice, y entonces vemos al rey, su cara de perfil y enorme que ocupa toda la hoja, con rasgos duros, en una posición estática, en colores grises con la corona, el elemento que lo destaca como de la realeza. Esta corona parece de metal pero no precioso y con una forma que se asemeja a una pieza de máquina. Los pobladores, en cambio, se ven de perfil y más pequeños pero con la figura completa aunque completos y en posición dinámica. 


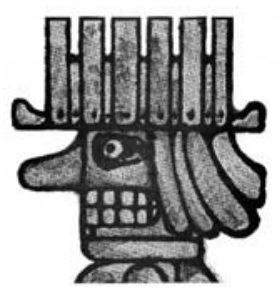

Figura 12. Doumerc, B. Y Barnes, A. El pueblo que no quería ser gris. Caba: Colihue, 2015.

Esta manera de representar a los personajes del pueblo, con pocas líneas, de perfil, de forma sintética es característico de Barnes y nos recuerda al hombrecito de La línea, entre otros. La situación absurda en la que queda el rey que "se cayó de espaldas una sola vez, pero tan fuerte que no se levantó más", luego de caer de espaldas una y otra vez de forma cómica, absurda, también es similar al burgués ruso de Lébedev en El helado transformado en muñeco de nieve.

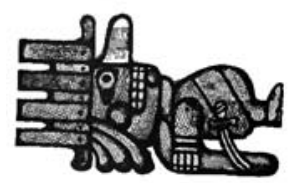

Figura 13. Doumerc, B. Y Barnes, A. El pueblo que no quería ser gris. Caba: Colihue, 2015.

El gordo burgués de Lébedev se excede en el consumo y peca de gula, mientras que el rey del pueblo que no quería ser gris termina completamente desautorizado luego de no lograr que se cumplan sus órdenes autoritarias y absurdas.

La técnica de pintura, con tintas diluidas, es muy similar a otra técnica que experimenta Barnes con un libro para niños llamado Aserrín, aserrán y en algunos cuadros de mujeres y gatos que realizó con brea diluida con solvente ${ }^{8}$. Barnes, al modo de los vanguardistas de comienzos de siglo, trabaja e investiga con nuevos materiales y crea otra vez, con elementos nuevos y no tradicionales para la pintura de caballete. Destacamos, además, que la misma búsqueda de nuevos materiales que utiliza para los cuadros, elige repetirla en las propuestas para los niños.

Esta decisión de Barnes de no subestimar al niño y ofrecerle lo mismo que al adulto, implica una concepción de infancia determinada y particular: un niño que merece apropiarse del arte. Muy semejante es esta visión con la del ilustrador ruso. La experimentación como artistas con nuevos materiales y técnicas la ponen en juego en todos sus trabajos sin distinción de edad del receptor para ofrecer propuestas artísticas potentes, además, en la comunicación precisa.

Tanto en los carteles de la Rosta de Lébedev como en los afiches de Barnes en la Imprenta AS notamos una fuerte búsqueda por la comunicación masiva, directa, clara y con bajos 
recursos. Y más tarde, estas mismas características las sostienen para su trabajo con las imágenes que crean para los libros infantiles. En ambos artistas, el antecedente con estos trabajos marcó sus creaciones futuras que podemos adivinar en las imágenes futuras para niños.

\section{Proyectos de publicación de libros para niños.}

Lébedev participó en proyectos muy comprometidos de los años de la Revolución con la educación y la difusión de la cultura del Nuevo Estado. En 1923, convocado por Maxim Gorki que se desempeñaba como director responsable del departamento de libros infantiles de GIZ (Ediciones del Estado) que funcionó hasta 1933, Lébedev se ocupó de la dirección artística de estas ediciones junto con Samuil Marshák. Allí se desarrolló una propuesta nueva en los libros para niños como lo anuncian desde el prefacio del catálogo de GIZ:

Para que la literatura no sea una simple distracción, sino algo serio y apasionante para cada niño, es necesario que el libro encienda su ánimo contra todo lo caduco, lo podrido y todo lo que impide construir el socialismo. Es preciso que, desde la infancia, la literatura eduque a cada niño como un hombre que sabe poner su voluntad al servicio de la colectividad colectiva...Y como última exigencia pedimos un alto nivel artístico (Cit. en: Pérez y Lévéque, 2012, p. 91).

Como decíamos, es imprescindible considerar "los carteles de la Rosta" en los que trabajó Lébedev al momento de recorrer su obra para niños. Ambos receptores, el público analfabeto de los carteles y los niños de los libros infantiles, se vinculaban en cuanto a falta de experiencia en la lectura de textos y la forma de resolver este inconveniente a través de la gráfica, las ilustraciones. El diseño de los carteles y de los libros se caracterizan por la legibilidad de las imágenes, lo figurativo de las mismas a pesar del grado de abstracción que poseen y su carácter narrativo, casi es posible seguir el relato sin leer el texto y mirando los dibujos. La especialista Misler, que analizó su obra, resalta justamente el interés de Lébedev por la comunicación y la producción masiva de cualquier tipo de expresión como las revistas, los carteles, o los libros infantiles. (Misler, 2012, p. 71) Prácticamente es posible leer El helado o Ayer y hoy sin necesidad de la lectura de los textos.

Koval se detiene en la destreza de Lébedev que demuestra desde sus primeros trabajos en las revistas satíricas y nos confirma lo que proponemos cuando justamente lo vincula con el libro infantil:

Así, por ejemplo, en las ilustraciones de La historia se repite (Tras la batalla de Kalka) se representa de forma grotesca y afilada a los orondos comerciantesespeculadores que se enriquecían con los desastres y calamidades de la guerra, jugando a las cartas sobre los cuerpos de los soldados rusos. En estos negativos prototipos humanos se presienten ya las futuras imágenes satíricas del burgués ruso de sus carteles o el hombre gordo del libro Morózhennoye (El helado) (1925) (Koval, 2012, p. 14). 
Por su parte, Barnes también participó en proyectos muy innovadores de la literatura infantil pero, en cambio, los llevaron a cabo editoriales que no dependían del Estado como el CEAL. Esta editorial la funda Boris Spivacow en 1967. Este reconocido editor comenzó su tarea en este campo en los años ' 50 en la editorial Abril que publicó la colección Bolsillitos y Gatitos. Díaz Rönner, la especialista en literatura para niños, marca el momento inicial de un cambio en estos libros que se apartaban de la literatura publicada habitualmente para la infancia, siempre encapsulada en los textos escolares:

Sin embargo, a principios de esos años nace la formidable colección "Bolsillitos" de Abril, dirigida por el editor Boris Spivacow, con venta en quioscos y en pleno auge de la cultura popular de la época. Del mismo modo, fuera del mencionado acordonamiento del campo cultural infantil, se publicaron libros de Javier Villafañe, Conrado Nalé Roxlo, de María Granata, que permitieron un leve ablandamiento de aquellas líneas duras, más apegadas a una pedagogización de lo moral que a dar rienda suelta a la imaginación (Díaz Rönner, 2011, p. 47).

Es necesario señalar que hay acuerdo en postular que los años sesenta constituyen un punto de inflexión en la literatura para niños en nuestro país, que se traduce en una polémica que empieza a enfrentar dos posturas encontradas. Por un lado, algunos representantes de la corriente didáctica de esos tiempos sostenían que los cuentos para niños no debían ser truculentos, demasiado tristes y se ponían en valor aquellos que, explícitamente se ocuparan de proponer un mensaje moralizante y didáctico. Por el otro lado, algunos autores, como María Elena Walsh o Javier Villafañe, proponían una alternativa: una literatura más innovadora que sentaría las bases de un movimiento diferente con una nueva visión acerca de la infancia y de los libros y productos culturales que se creaban para ellos.

En esta última vertiente ubicamos a Boris Spivacow que, previamente a fundar el CEAL, es convocado como director de la editorial Eudeba, que en estos primeros años publica libros en forma masiva hasta 1966 cuando "La noche de los bastones largos" trunca el proyecto y Spivacow abandona la editorial universitaria. Este editor funda una nueva al año siguiente, con la colaboración de muchos individuos que son convocados para participar económicamente con una propuesta innovadora y rupturista y así comienza el enorme proyecto del CEAL. Con el lema "Más libros para más", se comienzan a publicar libros y publicaciones de bajo precio en forma masiva de los más diversos temas, en formato económico pero con contenido diverso y preciso, con la modalidad de venta en los quioscos de diarios. De este modo logran una amplia distribución en todo el país. En una entrevista, Beatriz Sarlo que trabajó en la editorial, aseguró que:

Boris estaba convencido, más allá de todo razonamiento, de que el arte y la cultura mejoraban a los pueblos. (...) Aunque Boris fue militante del Partido Comunista, tuvo -como tantos otros militantes- la convicción de la fuerza pedagógica de la cultura que formaba parte del continente de la ideología socialista. La cultura, junto con la lucha política, son los dos grandes elementos de transformación de las sociedades (Cit. en: Maunás, 1995, p. 197). 
En esta editorial se lanzan dos colecciones para niños. La primera en 1967, los cuentos Polidoro y en 1970, los Chiribitil. Nos interesa especialmente centrarnos en los Polidoro en los que Barnes colaboró en muchos fascículos.

Los cuentos de la colección Polidoro del CEAL incluían cuentos tradicionales como los de Perrault, los hermanos Grimm o Andersen, leyendas orientales y americanas, los mitos griegos o la Biblia, traducidos, adaptados o versionados en forma libre por Beatriz $\mathrm{Fe}$ rro, Horacio Clemente y otros autores argentinos. Las ilustraciones fueron realizadas por grandes artistas como Ayax Barnes, Napoleón, Oscar Grillo, Hermenegildo Sábat, entre otros y esto se transformó en su sello distintivo. Publicados primero en forma de fascículos, más tarde se vendieron en otros formatos (como antologías, por ejemplo). A propósito de la reedición reciente de algunos de estos cuentos por parte del Ministerio de la Nación de nuestro país en 2015, para ser distribuidos en las escuelas públicas, incentivada la reedición por la premiada autora de libros para niños Isol, la especialista Judith Gociol proclamaba en la presentación en la Feria del Libro de mayo de 2015:

Los Polidoros explotaban el humor, la ironía, el absurdo y el desparpajo con un lenguaje directo y cotidiano, en un abanico que va de cuentos duramente crueles a historias de inmensa poética. (...) El mayor impacto lo causaba $-\mathrm{y}$ todavía lo causa- el tratamiento gráfico de la serie: bellas y variadas técnicas pictóricas y de diseño que sorprendían, desconcertaban y provocaban a los chicos en un momento en que los dibujos estaban más bien relegados a una función de paratextos. Aquí las imágenes no acompañan a las palabras sino que posibilitan una lectura independiente. Los Polidoros fueron ilustrados por dibujantes sabiamente detectados, que por esos años publicaban sus primeros trabajos y luego fueron reconocidos artistas 9 .

Las ilustraciones para esta colección de Ayax Barnes en particular, se distinguen por la influencia de corrientes vanguardistas, además de otros proyectos de diseño como los carteles polacos, la estética de Heinz Edelmann (como director artístico de la película y el álbum Yellow Submarine de Los Beatles) y los trabajos del Push Pin Studios. Las imágenes de Barnes para estos cuentos se distinguen por ser funcionales al relato, nada estereotipados y por añadidura, muestran una gran destreza para distribuirse en las páginas logrando resolver la restricción de forma muy eficaz para no ocupar más pliegos de los necesarios para que la publicación sea económica. Algunos ejemplos de estos procedimientos de diseño son las imágenes superpuestas al texto, los dibujos insertos entre los párrafos, entre otros. El mérito del innovador diseño es además del reconocido diseñador de la editorial: Oscar "El negro" Díaz. 


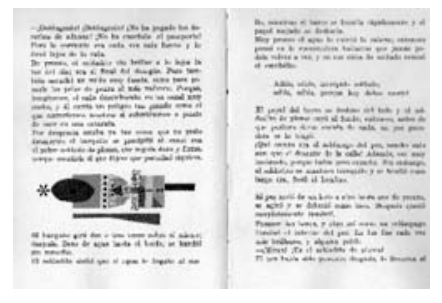

Figura 14. Cuentos

Polidoro. Buenos Aires:

CEAL, 1967.

La colección Polidoro fue tan innovadora en cuanto al diseño y la ilustración que muchos especialistas acordamos en que fue pionera en la literatura infantil moderna de nuestro país, los libros-álbum. Aunque sostenemos que sigue siendo original y única en la publicación de libros de tan alta calidad para niños, de bajo costo para el acceso masivo.

\section{Conclusión}
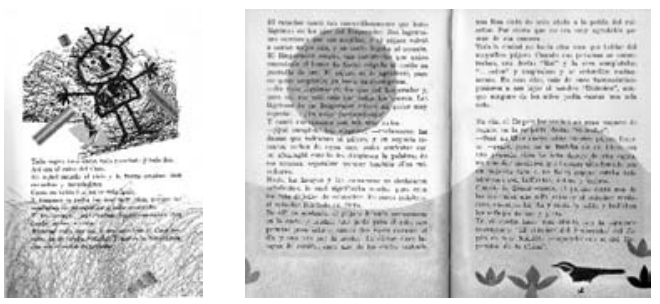

Lébedev y Barnes tuvieron una trayectoria profesional con puntos en común como el trabajo como diseñadores de carteles o afiches para la comunicación masiva. Aunque con diferencias, también vivieron en contextos históricos revolucionarios. Ambos respondían a ideologías semejantes y llegan a elecciones estéticas similares dentro de las vanguardias que buscan el vínculo entre el arte y la praxis vital. De allí que estos ilustradores se vuelcan por el contenido real y social en sus imágenes en toda su obra.

El trabajo que realizaron en los libros para niños también nos permite reconocer una muy semejante configuración de niño como receptor de un producto artístico. Cada uno desde su lugar y su tiempo, imaginó a la infancia y eligió una manera de dirigirse a ella.

Los críticos Pérez y Lévéque concluyen acerca de Lébedev que:

Así, sin traicionar su firme opción por las propuestas del arte moderno, logró fórmulas nuevas a través de una síntesis entre la estampa popular, el cartel, el dibujo infantil y las aportaciones gráficas de vanguardia. Por esa importante contribución, en la actualidad se reconoce a Lébedev como uno de los autores 
que fijó las bases de la ilustración moderna de libros para niños (Pérez y Lévéque, 2012, p. 88).

Nos animaríamos a postular que, con sus particularidades, pero también con elecciones similares al ilustrador ruso, Barnes constituye hoy uno de los principales referentes de la ilustración moderna argentina de libros para niños.

\section{Notas}

1. La primera edición rusa de estos cuentos:

Marshák, M. y Lébedev, V. (1925) Morózhenoye (El helado), Moscú; Leningrado: Rodega. . (1925) Vcherá i Segódnia (Ayer y hoy), Moscú: GIZ.

2. Esta política que restablecía temporalmente el capitalismo implicó la restauración, entre otras cosas, tanto de las iniciativas privadas como de los negocios de todo tipo y las profesiones. Los nepman, como se los denominó, eran los nuevos burgueses que se convirtieron en los estereotipos caricaturescos ya que la sociedad soviética no los apreciaba. De allí que fueran satirizados en la prensa comunista y las revistas satíricas.

3. Cf. Povelíjna, A. y Kovtún, Y. (1991) Russian Painted Shop. Signs and Avant-Garde Artists. Leningrado: Aurora. Citado por Koval en el Catálogo.

4. Kúdok, V. (1994) Agenda de años y días. Memorias del artista. San Petersburgo: Arsis, p. 60. Citado por Masha Koval en el Catálogo.

5. Imagen disponible en: Vladimir Lébedev (1891-1967). (2012) Catálogo de la muestra. Museo de Arte Abstracto Español. Fundación Juan March. Cuenca. España. Disponible en: https://www.march.es/arte/catalogos/ficha.aspx?p0=cat\%3A140\&p1=28

6. Imagen disponible en: Vladimir Lébedev (1891-1967). (2012) Catálogo de la muestra. Museo de Arte Abstracto Español. Fundación Juan March. Cuenca. España. Disponible en: https://www.march.es/arte/catalogos/ficha.aspx?p0=cat\%3A140\&p1=28

7. Dictamen del Jurado que premió La línea en 1975: "Altamente original, con gracia y humor logra dar, para toda edad, con un poder de síntesis notable, una visión del mundo contemporáneo". Los miembros del jurado del premio Casa de las Américas en 1975 fueron María Escudero (Argentina), Javier Villafañe (Argentina), Joaquín Gutiérrez (Costa Rica), Rogelio Paulo (Portugal) y Onelio Jorge Cardoso (Cuba). Copia del original provisto por la Asociación Casa de las Américas.

8. La información acerca de la técnica de trabajo en estos libros fue facilitada por el artista gráfico argentino Juan Lima.

9. Palabras pronunciadas el $11 / 5 / 2015$ en la $41^{\text {a }}$ Feria Internacional del Libro de Buenos Aires, con motivo de la presentación de la reedición de los cuentos Polidoro por parte del Ministerio de Educación para su distribución en las escuelas del país. Texto facilitado por la autora. 


\section{Bibliografía literaria}

Doumerc, B. y Barnes, A. (2015). La línea. Caba: Ediciones del Eclipse.

Doumerc, B. y Barnes, A. (2015). El pueblo que no quería ser gris. Caba: Colihue.

El intrépido soldadito de plomo, en: (1967) Cuentos Polidoro. (versión de Beatriz Ferro e ilustraciones de Ayax Barnes). Buenos Aires: CEAL.

Marshák, S. y Lébedev, V. (1925). El helado (Morózhenoye). Moscú, Leningrado: Ráduga. Disponible en: https://digitalcollections.lib.washington.edu/digital/collection/childrens/ id $/ 2312$

Marshák, S. y Lébedev, V. (2013). The circus and other stories. London: Tate.

\section{Bibliografía}

Argan, G. C. (1991). El Arte Moderno. Del iluminismo a los movimientos contemporáneos. Madrid: Akal.

Bürger, P. (2000). Teoría de la vanguardia. Barcelona: Ed. Península.

Carmona, E. (2008). "Fondo y figura del Cubismo y sus entornos." En: AA.VV., El Cubismo y sus entornos. Catálogo de Exposición en el Museo Nacional de Bellas Artes. Buenos Aires: Telefónica.

De Micheli, M. (1999). Las vanguardias artísticas del siglo XX. Madrid: Alianza.

Díaz Rönner, M. A. (2011). La aldea literaria de los niños. Córdoba: Comunicarte.

Gilman, C. (2012). Entre la pluma y el fusil. Debates y dilemas del escritor revolucionario en américa latina. Buenos Aires: Siglo veintiuno.

Koval, M. "Vladímir Lébedev. Un retrato del artista". En: (2012) Vladimir Lébedev (18911967). Catálogo de la muestra. Museo de Arte Abstracto Español. Fundación Juan March. Cuenca. España. Disponible en: https://www.march.es/arte/catalogos/ficha. aspx?p $0=$ cat $\% 3 \mathrm{~A} 140 \& \mathrm{p} 1=28$

Krause, F. (2017). La lectura del artista Ayax Barnes a través de sus ilustraciones de los cuentos de Andersen en la edición de los Polidoro del Centro Editor de América Latina. Tesis de Especialización en Literatura Infantil y Juvenil. UNSAM (Universidad Nacional de San Martín) - sin publicar.

Krause, F. “Sucesión de hechos: los puntos que hicieron La línea. Algunas consideraciones de su producción y circulación”. En: (2015) Separata que acompaña a la edición conmemorativa de los 40 años del Premio Casa de las Américas del libro La línea. Caba: Ediciones del Eclipse.

Lodder, C. (1988). El Constructivismo ruso. Madrid: Alianza.

Maunás, D. (1995). Boris Spivacow. Memoria de un sueño argentino. Buenos Aires: Colihue. Misler, N. "Un arte público: las caricaturas y los carteles de Vladímir Lébedev". En: (2012) Vladimir Lébedev (1891-1967). Catálogo de la muestra. Museo de Arte Abstracto Español. Fundación Juan March. Cuenca. España. Disponible en: https://www.march.es/arte/ catalogos/ficha.aspx?p0 =cat\%3A140\&p1=28 
Pérez, C. y Lévéque, F. "Vladimir Lébedev. El arte moderno en los cuentos para niños". En: (2012) Vladimir Lébedev (1891-1967). Catálogo de la muestra. Museo de Arte Abstracto Español. Fundación Juan March. Cuenca. España. Disponible en: https://www.march. es/arte/catalogos/ficha.aspx?p0 $=$ cat $\% 3 \mathrm{~A} 140 \& \mathrm{p} 1=28$

\begin{abstract}
Vladimir Lebedev (1891- 1967) adhered to historical vanguard movements for the creation of children's book images that were part of a special publication program held during the Russian Revolution. My hypothesis is that his work influenced that of Ayax Barnes (1926-1994), an Argentine illustrator who took part in innovative children's books projects in Argentina in the 60s and 70s.

Through my analysis, I intend to show that, in spite of the fact that they were far from each other, both in time and space, there are parallelisms in terms of their aesthetic choices, the art movements that influenced them, and the communicative intention of their illustrations, which were socially and politically committed.

Keywords: Children's books - Ilustrations - Vanguards - Committed artists - Aesthetic choices.

Resumo: Vladimir Lébedev (1891-1967) subscreve as correntes vanguardistas históricas para a criação de imagens de livros infantis em um programa especial de publicações na Revolução Russa. Minha hipótese é que seu trabalho influenciou no de Ayax Barnes (1926-1994), ilustrador argentino que participou de projetos inovadores de livros para crianças durante os anos sessenta e setenta na Argentina.

Minha análise mostra que, apesar da distância temporal e geográfica entre eles, é possível estabelecer paralelismos quanto às escolhas do ponto de vista estético, das correntes artísticas que os influenciam e da intencionalidade comunicativa de suas ilustrações, relacionada ao comprometimento social e político.
\end{abstract}

Palavras chave: Livros infantis - Ilustrações - Vanguardas - Artistas engajados - Escolhas estéticas.

[Las traducciones de los abstracts fueron supervisadas por el autor de cada artículo] 